\title{
Pensononomoor
}

2018, vol. 79, 20-33

http://dx.doi.org/10.12657/denbio.079.003

\author{
Maksym Netsvetov, Yulia Prokopuk, Yakiv Didukh, \\ Maksym Romenskyy
}

\section{Climatic sensitivity of Quercus robur L. in floodplain near Kyiv under river regulation}

\author{
Received: 26 February 2017; Accepted: 11 October 2017
}

\begin{abstract}
Climate change has a significant impact on natural ecosystems, particularly on floodplain forests that are among the most transformed ecosystems in the world. The climate sensitivity of dominant species is likely to play a key role in determining the susceptibility of flooded forests to climate changes. Here, we use dendrochronological approaches and local climate records from 1880 to 2015 to assess the response in pedunculate oak (Quercus robur L.) trees growing in a floodplain of the Dnipro River near Kyiv to climatic variables. Correlation analysis reveals the strongest positive association of the Q. robur tree-ring width chronology with May-June precipitation, May-June temperature, and May self-calibrating Palmers drought severity indices (scPDSI). The moving-window correlation analysis points to positive association with the scPDSI after the 1950s, when local river regulation was implemented. The positive correlation with current March precipitation is the least expected change in the oak growth-to-climate relationship that occurred in the aftermath of human alterations in the local river and regional climate changes. This study discusses the probable ecological consequences and ecophysiological mechanisms of observable climate-to-growth relationships and their temporal stability.
\end{abstract}

Keywords: pedunculate oak, tree-ring width, riparian forest, dendroclimatology, moving correlation

Addresses: M. Netsvetov and Yu. Prokopuk, Institute for Evolutionary Ecology of the National Academy of Sciences of Ukraine, 37, Lebedev St., 03143, Kyiv, Ukraine, e-mail: disfleur76@live.fr

Ya. Didukh, M.G. Kholodny Institute of Botany of the National Academy of Sciences of Ukraine, 2, Tereshchenkivska St., 01601, Kyiv, Ukraine

M. Romenskyy, Department of Mathematics, Uppsala University, Box 480, Uppsala, 75106, Sweden

\section{Introduction}

Floodplain forests represent ecosystems that provide essential habitats and food resources for diverse plant and animal species (Gren et al., 1995; Bauer et al., 2010), reduce soil erosion, perform water regulation, improve water quality, supply material for wood products, and provide people with recreation (Gren et al., 1995; Klimo, 1998). However, riparian and flooded ecosystems are likely to be highly vulnerable to climate change and human impact (Turner et al., 2004; Schnitzler et al., 2005; Kaminski et al., 2011; Capon et al., 2013) and thus need to be understood through their relationship with environmental variables.

As climate change manifested itself by warming and varying precipitation patterns, it exerts an influence 
on riverine ecosystems, altering impact on rivers' hydrology (Middelkoop et al., 2001; Kundzewicz, 2008; Schneider et al., 2013) that directly affects floodplain ecosystems biota (Poff et al., 1997; Ström et al., 2011; Politti et al., 2014; Morid et al., 2016). An ecosystem's capacity to adjust to climate change largely depends on morphological and physiological plasticity of its components (Capon et al., 2013). The ability to cope with soil-water excess and root hypoxia, which enables persistence of trees under fluctuating soil-water level, differs among tree taxa. For instance, Fagus sylvatica L. and Quercus petraea Matt. Liebl. belong to a very low flooding tolerance class, whereas, Alnus glutinosa L. and Salix alba L. are among highly flood-tolerant species (Glenz et al., 2006). Pedunculate oak (Quercus robur L.), on the contrary to its congener species $Q$. petraea, is known to be tolerant to flooding and is able to withstand 50 days flooding in its juvenile stage and up to 100 days flooding as adult (Siebel et al., 1998; Kreuzwieser et al., 2004; Glenz et al., 2006).

Flood during the onset of earlywood growth is known to cause formation of anomalous anatomical structures, i.e. collapsed sickle-shaped vessels, but in both juvenile (Copini et al., 2016) and adult (Stuijfzand et al., 2008) Q. robur trees this happens only in the submerged part of the stem and is attributed to hypoxia. Flood has a significant negative effect on the ring width only in juvenile oaks (Copini et al., 2016), but in contrary may result in wider tree rings in adult trees (Gričar et al., 2013). Oak growth is positively affected by May-June precipitations, particularly when hydrology is altered and floods occur in winter-spring at many flooded sites in Central Europe (Čater \& Levanič, 2015; Goršić, 2014; Stojanović et al., 2015b; Hafner et al., 2015).

The oak radial growth response on temperature in the growing season is ambiguous, being negative at sites with regulated rivers (Goršić, 2014; Stojanović et al., 2015a; Stojanović et al., 2015b), and absent or positive where river regulation is not imposed (Čejková \& Poláková, 2012; Scharnweber et al., 2013; Hafner et al., 2015; Tumajer \& Treml, 2016). The high positive temperature signal in tree-ring chronology is possibly a consequence of sufficient water availability during wood formation (Tumajer \& Treml, 2016). Moreover, the $Q$. robur decline and rise in its mortality rate are expected to be more common phenomena in the future, in the regions where global warming leads to an increase in annual precipitation and in frequency of extreme rainfall events (Rozas \& García-Gonzáles, 2012). The oak decline and decrease in wood production also happen in areas experiencing excess of water in winter-spring and drought events in summer during the growing season (Lévy et al., 1999; Vincke \& Delvaux, 2005). This effect is in line with the finding that wet and warm conditions in spring can exacerbate the summer drought effect by promoting the formation of large-sized earlywood vessels (Tumajer \& Treml, 2016), as large vessels are able to transfer greater volumes of water while abundant, but vulnerable to cavitation and embolism under soil-water deficit (Sperry et al., 2008).

Consistent patterns of relationships for floodplain Q. robur and climate variation are still mainly uncertain probably due to the various hydrological regimes over different sites coupled with the effect of regional climate trends. Even relatively short meteorological and hydrological recordings point out a recent climate trend effect on tree growth in flooded sites (Stella et al., 2013; Tumajer \& Treml, 2016). Obviously, longer series of both the tree-ring and the climate variables are desirable to more comprehensively appreciate how climate controls oak growth in floodplains.

The objective of this study was to assess how climate variables governed $Q$. robur radial growth since 1880 in an extant old-growth floodplain forest near Kyiv, Ukraine. The long-term climatic records and ring-width chronology sampled from living trees growing in the Siverka River valley, which is a tributary of the Dnipro River, were used to compute the correlation function over the entire 136-yr interval and the 102 consecutive 35 -yr intervals. Changes in the correlation function coefficients were compared with 35-yr level of smoothing, fitted to monthly climate records, with respect to the date of the river regulation onset. Our general expectation was that the regional warming trend coupled with river flow alteration enhanced a detrimental effect of water deficit and summer temperatures on oak growth in a floodplain. We also suggest that well documented historical floods had a negative effect on studied trees before the river regulation was implemented.

\section{Material and Methods}

\section{Study site}

The studied site is located in the southern part of Kyiv ( $\left.50^{\circ} 17^{\prime} 40^{\prime \prime} \mathrm{N}, 30^{\circ} 32^{\prime} 57^{\prime \prime} \mathrm{E}\right)$ and pertains to the Lisnyky Reserve of the National Natural Park "Holosiivsky". The Lisnyky Reserve spans an area of 1110 ha with altitudes ranging from 93 to $115 \mathrm{~m}$ a.s.l. The eastern part of the Lisnyky forest is dominated by Scots pine (Pinus sylvestris L.) on poor sandy soils, and the western part, including the studied site, is represented by deciduous species on acidic sod-podzolic gley soil. The western portion of the reserve is situated between the Siverka River and its tributary the Petyl River. There is a low-lying site at $93 \mathrm{~m}$ a.s.l. that is abundant with sedge bogs, oxbows, and swampy alder-woods here. In more elevated locations (94-97 $\mathrm{m}$ a.s.l.) of the western portion, the dominant forest associations are the Convallario 
majali-Quercetum roboris Shevchyk et V. Solomakha 1996 and the Quercetea robori-petreae. The overstory here is dominated by $Q$. robur and the midstory is comprised by Tilia cordata Mill., Fraxinus excelsior Mill., Acer platanoides L., A. campestre L. and A. tataricum L. (Didukh \& Aloshkina, 2012).

The studied site historically experienced flooding in spring before the river regulation was implemented (Vishnevsky, 2007). Following the 1950s channelization and channel straightening of the Siverka River, the deep natural flooding in the Lysnyky forest ceased. Since the 1976, when a levee downstream of
Kyiv was built, the river's water is backed up by the main stream, i.e. the Dnipro River. In the 2000s, the drainage construction was partially dismantled and filled in, causing flooding in spring. The Siverka River's rain-snow regime makes it full in April-May and nearly dried up in July-August (Vishnevsky, 2007).

\section{Climatic data}

The regional monthly temperature and precipitation records were obtained from the Central Geophysical Observatory CGO in Kyiv, 165 m a.s.l., and
(A)

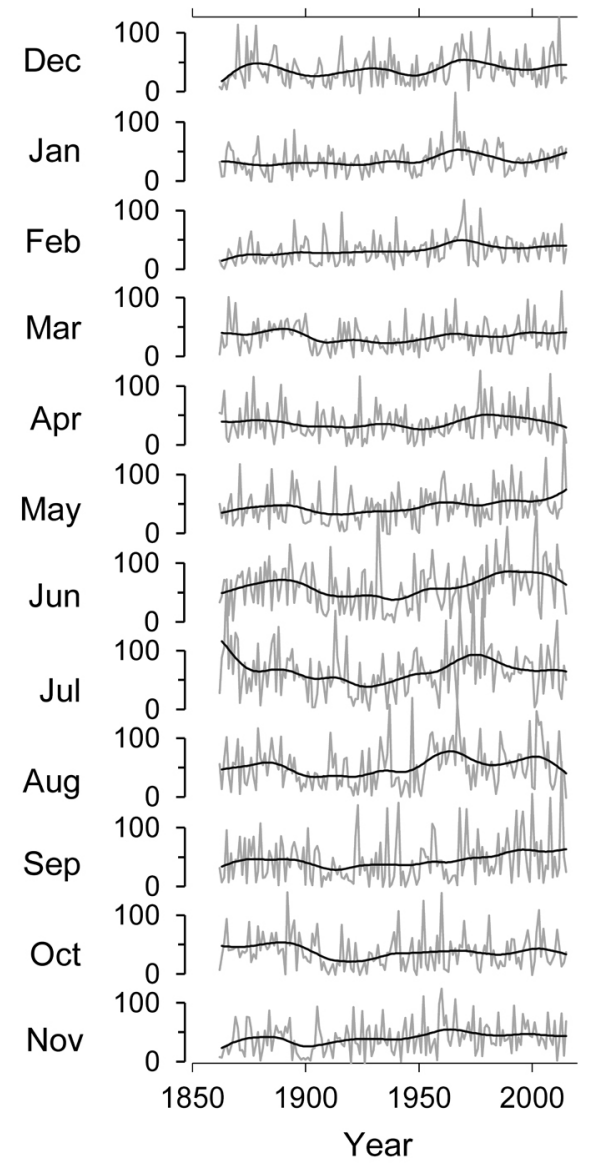

(D)

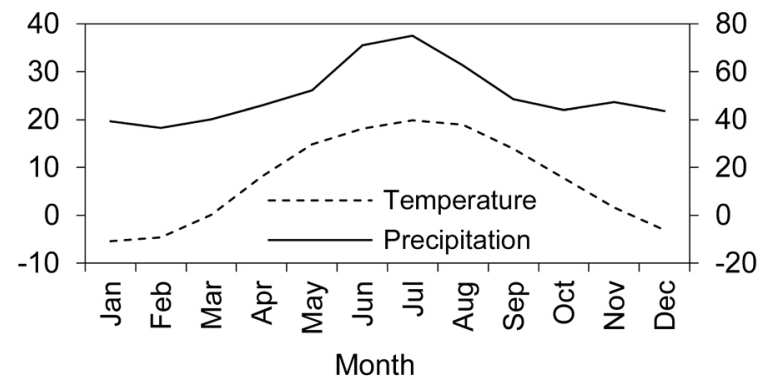

(B) Temperature, ${ }^{\circ} \mathrm{C}$

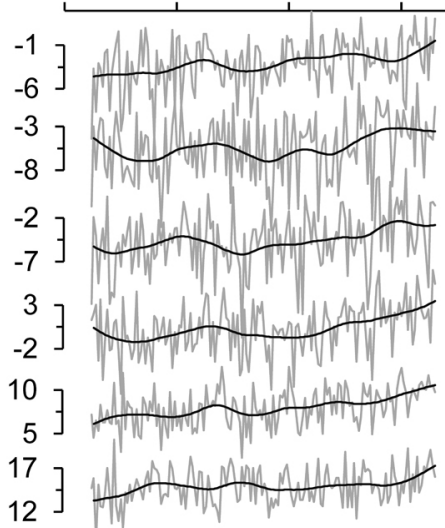

21

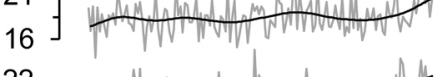

22 17 ]

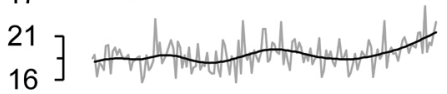

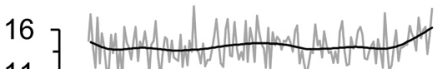

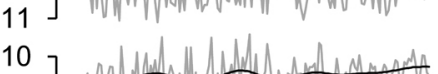

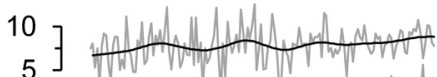

$\left.\begin{array}{r}3 \\ -2\end{array}\right]$

$-2$

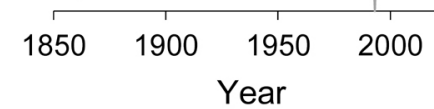

(C) ScPDSI

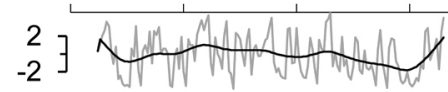

${ }_{-2}^{2}$ 工

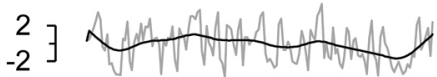

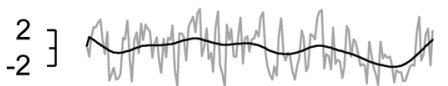

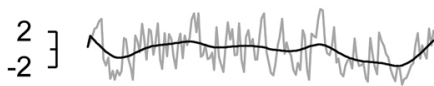

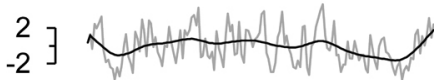

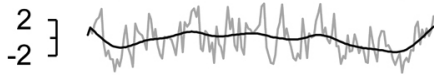

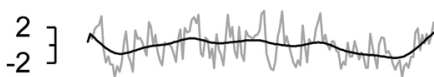

$2]$

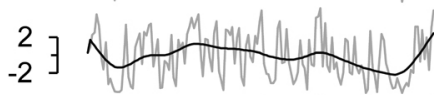

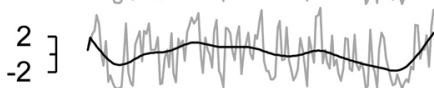

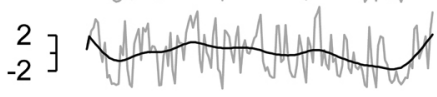

$1850 \quad 1900 \quad 1950 \quad 2000$

(E) -0.4

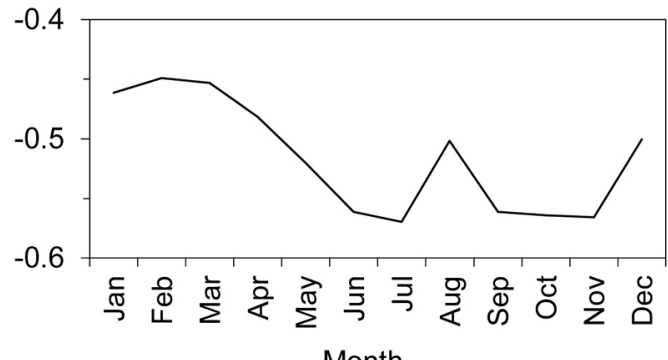

Fig. 1. Inter-annual variations in precipitation (A), temperature (B), and self-calibrating Palmer Drought Severity Index (C); the composed residual chronology of ring-width indices RWI (D), and the number of trees (E). The black lines in panels $(\mathrm{A}-\mathrm{C})$ represent the 15-yr spline smoothing. The panels D and E refer to the period 1880-2015 
$10.5 \mathrm{~km}$ north-west of the study site. The self-calibrating Palmer Drought Severity Indices (scPDSI) were derived from climatic data, and the available soil-water storage capacity was extracted from Global Soil Texture and Derived Water-Holding Capacities (Webb et al., 2000). The scPDSI calculation was performed using Zang's R-codes that are available online (https://github.com/cszang).

The climate records indicate a known warming trend in temperature, but no long-term change in precipitation in Kyiv during the past 150 years (Fig. $1 \mathrm{~A}, \mathrm{~B})$. The one and a half century of scPDSI variation shows several periods 1865-1900, 1940-1960, and 1970-2010, during which a short-term increase in the soil-water deficit occurs (see gray line in Fig. 1 C). The records show that the maximal precipitation value of $75 \mathrm{~mm}$ occurs in July and the lowest value of $37 \mathrm{~mm}$ occurs in February (Fig 1. D). Since 1863 the average total annual precipitation value is $606 \mathrm{~mm}$. The monthly mean temperature ranges from $-5.4^{\circ} \mathrm{C}$ in January to $19.8^{\circ} \mathrm{C}$ in July (Fig. $1 \mathrm{D}$ ), while the annual temperature averages $7.5^{\circ} \mathrm{C}$. The obtained scPDSI monthly mean values were below 0 during the year indicating an overall soil-water deficit in Kyiv (Fig. 1 E).

\section{Field sampling and data analysis}

We selected 40 old dominant trees that did not show any visual evidence of stem damage and decay to take wood samples. The studied trees grew in a site with the area of about 42 ha and with an altitude differential of about $4 \mathrm{~m}$. The age of studied trees was from 86 to 163 years, while the age of 83 percent of the trees ranged from 121 to 158 years. The studied trees were located at distances of 35-180 m from the river or oxbows.

During spring-summer 2016, we extracted at least two cores per tree at breast height, using an increment borer. Each core was air-dried, glued onto wooden supports and surfaced. Then, the cores were scanned at a resolution of 3200 dpi using an Epson V33 scanner. The tree-ring widths were measured employing AxioVision (Carl Zeiss) software to the nearest $0.001 \mathrm{~mm}$. To identify false rings, cores were thoroughly investigated under conventional microscopes (MBS-1 and Ulab XY-B2T LED).

The series from each individual tree were averaged to yield the individual ring-width chronologies. To reduce non-climatic effects on growth we fitted a cubic-smoothing spline and autoregressive model to each tree series. In order to build the mean residual chronology the individual series were averaged using a bi-weight robust mean. The tree-ring series were crossdated, standardized, and checked for errors using the COFECHA program, Version 6.06p (Holmes, 1983) and "dplR" package (Bunn, 2010) in R (R Core Team, 2016).

\section{Dendro-climatological analyses}

The relationship between annual variations in the oak residual chronology, and the monthly climatic variables, was investigated using the stationary and moving time-window correlation functions (Zang \& Biondi, 2015). The stationary correlation function spanned the climatic window from May of the previous growth season to October of the current growth season in the period 1880-2015 and two 66-year intervals before and during the Siverka River regulation that was implemented since 1950. The 16-months (for precipitation and temperature) window covers two successive growing seasons with intermittent dormant period. In order to respect the equality between the total number of climatic predictors and the time interval in the moving window correlation function, we considered temperature and precipitation data set only from prior-June to current August. The scPDSI data used in both versions of correlation function spans period from May to August of the only current growth period. Thus, the total number of climatic variables was 34 (15 for precipitation, 15 for temperature, and 4 for scPDSI) and 40 (18 for precipitation, 18 for temperature, and 4 for scPDSI) in the moving and stationary version, respectively. The interval to perform moving correlation analysis was 35 years. We used Gershunov's test (Gershunov et al., 2001) to decide whether the obtained correlations between growth and climatic variables are temporarily stable.

The superposed epoch analysis was performed to test the significance of a mean tree ring response to severe or extreme drought events that occurred over the interval from prior-September to current August. The raw tree-ring series were scaled, but not detrended or prewhitened in this analysis. The drought events expressed in the scPDSI were classified using Palmer's original categories of the PDSI (Palmer, 1965; Wells et al., 2004).

There were no records of ground-water level for the studied forest or the Siverka River hydrology information was available. We thus used the dates of well-documented, extreme flood events as well as the construction of dams and channel straightening (1950s) as possible reference points to interpret the growth-climate relationship stability. The superposed epoch analysis was performed to quantify the changes in tree ring width after flood events and to decide whether these changes were more pronounced in young trees. The superposed epoch analysis was applied to 4 flood events in the period before river flow regulation and to 3 events that happened in the period when more than $50 \%$ of studied trees were younger than 50 years.

All statistical calculations were performed using the "bootRes" and "treeclim" packages (Zang \& Biondi, 2013) in $\mathrm{R}$ software environment ( $\mathrm{R}$ Core Team, 2016). 


\section{Results}

\section{Tree growth and chronology statistics}

The Q. robur in the Lisnyky forest showed age-related growth trend, i.e. a decrease in the mean ring width with the tree age (Fig. $2 \mathrm{~A}$ ). The mean ring width reduced from $3.3 \pm 1.9 \mathrm{~mm}$ to $1.8 \pm 0.8 \mathrm{~mm}$, as the mean cambial age increased from 20 to 160 years, averaging $2.5 \pm 1.4 \mathrm{~mm}$ over the entire dataset (Fig. $2 \mathrm{~B})$. The mean and the residual versions of the treering width chronology spanned 160 and 159 years, respectively, ranging from 1866 to 2015 and from 1867 to 2015 (Fig. 2 C, D), and were obtained from 82 individual series of 40 trees (Fig. 2 E). The trees $<20,30,40$ and 50 years of cambial age represented more than 50 percent of the entire group until 1885 , 1886, 1908, and 1919, respectively (Fig. 2 F).
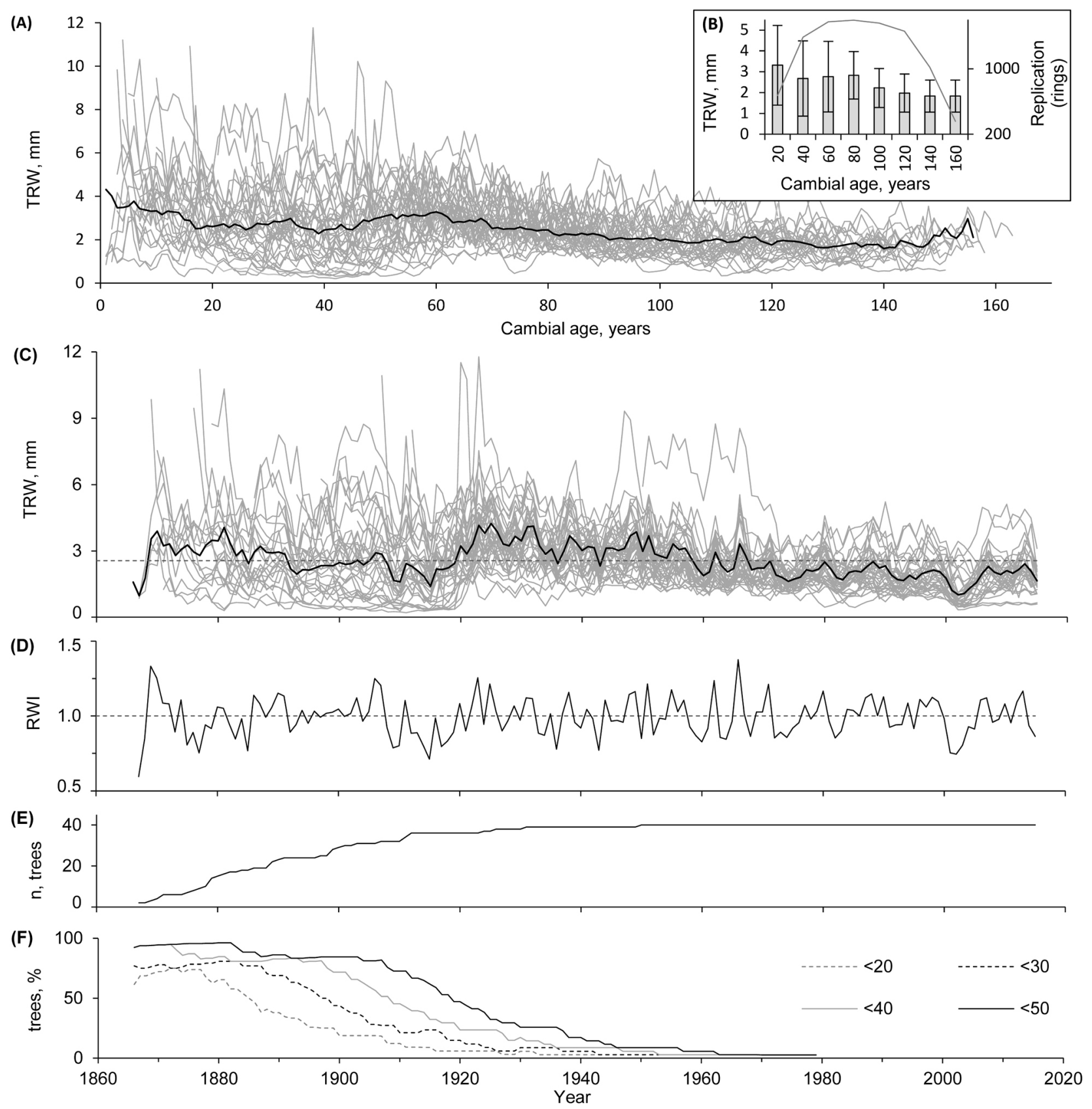

Fig. 2. (A) Quercus robur tree-ring width TRW (individual (gray lines) and mean (black line)) aligned by cambial age. (B) TRW (bars) distributed by age-classes and replication (line). (C) Raw chronologies of the tree-ring width (individual (gray lines) and the mean (black line)). (D) The composed residual chronology of ring-width indices RWI. (E) The number of trees. (F) Percentage of trees < 20, 30, 40, and 50 years of age. Horizontal dotted lines in plots (C) and (E) denote average values 
Table 1. Descriptive statistics of the ring width chronology of Quercus robur

\begin{tabular}{ccccccc}
\hline Time-span & cores & trees & $\mathrm{r}_{b t}$ & $\mathrm{r}_{\text {eff }}$ & EPS & SNR \\
\hline $1880-1914$ & 62 & 34 & 0.20 & 0.23 & 0.88 & 7.2 \\
$1895-1929$ & 75 & 38 & 0.29 & 0.35 & 0.95 & 17 \\
$1910-1944$ & 80 & 39 & 0.34 & 0.38 & 0.96 & 22.4 \\
$1925-1959$ & 82 & 40 & 0.32 & 0.38 & 0.96 & 23.5 \\
$1940-1974$ & 82 & 40 & 0.38 & 0.46 & 0.97 & 33.2 \\
$1955-1989$ & 82 & 40 & 0.35 & 0.42 & 0.97 & 28.3 \\
$1970-2004$ & 82 & 40 & 0.29 & 0.36 & 0.96 & 22.5 \\
$1880-2015$ & 87 & 40 & 0.30 & 0.38 & 0.95 & 21.1 \\
\hline
\end{tabular}

Note: $r_{b t}-$ correlation between trees, $r_{\text {eff }}-$ effective chronology signal.

EPS - expressed population signal, SNR - signal-to-noise ratio.

The between-tree correlation $\left(\mathrm{r}_{\mathrm{br}}\right)$ and the effective chronology signal $\left(\mathrm{r}_{\text {eff }}\right)$ calculated over the total chronology length were 0.30 and 0.38 , respectively, indicating a moderate strength of the common statistical signal (Table 1). The expressed population signal (EPS) exceeded 0.85 over the first 35-yr interval starting in 1880, suggesting an acceptable confidence level (Table 1). The signal-to-noise ratio (SNR), considered as a measure of chronology's quality, has reached a value above 20 in 1910 .

\section{Radial growth-climate relationships}

The correlation function revealed that oak ring width significantly correlated with 5 out of 34 climatic variables over the 1880-2015 interval (Fig. 3 A). In particular, the chronology was significantly $(\mathrm{p}<0.05)$ positively correlated with current March $(\mathrm{r}=0.22)$ and prior-August $(\mathrm{r}=0.19)$ precipitation, current May $(\mathrm{r}=0.21)$ and prior-June $(\mathrm{r}=0.19)$ temperature, and current May ( $\mathrm{r}=0.19)$ scPDSI. Correlations computed for the pre-1950 interval (Fig. 3 B) showed that growth before the Siverka River regulation was positively affected by May temperature, prior-November and current June precipitation, but was negatively affected with June temperature. Growth-climate relationships since 1950 (Fig. 3 C) had a clear shift toward stronger positive effect of precipitation in March and soil-water availability in May compared to earlier relationships, although precipitation in current October and temperature in previous August exerted a detrimental effect on $Q$. robur growth.

The correlation function with a 35-yr sliding window revealed that 12 out of 15 monthly precipitation variables significantly correlated with oak growth during one or more 35-yr intervals (Fig. 4). The positive correlation with current March (1934-1999),
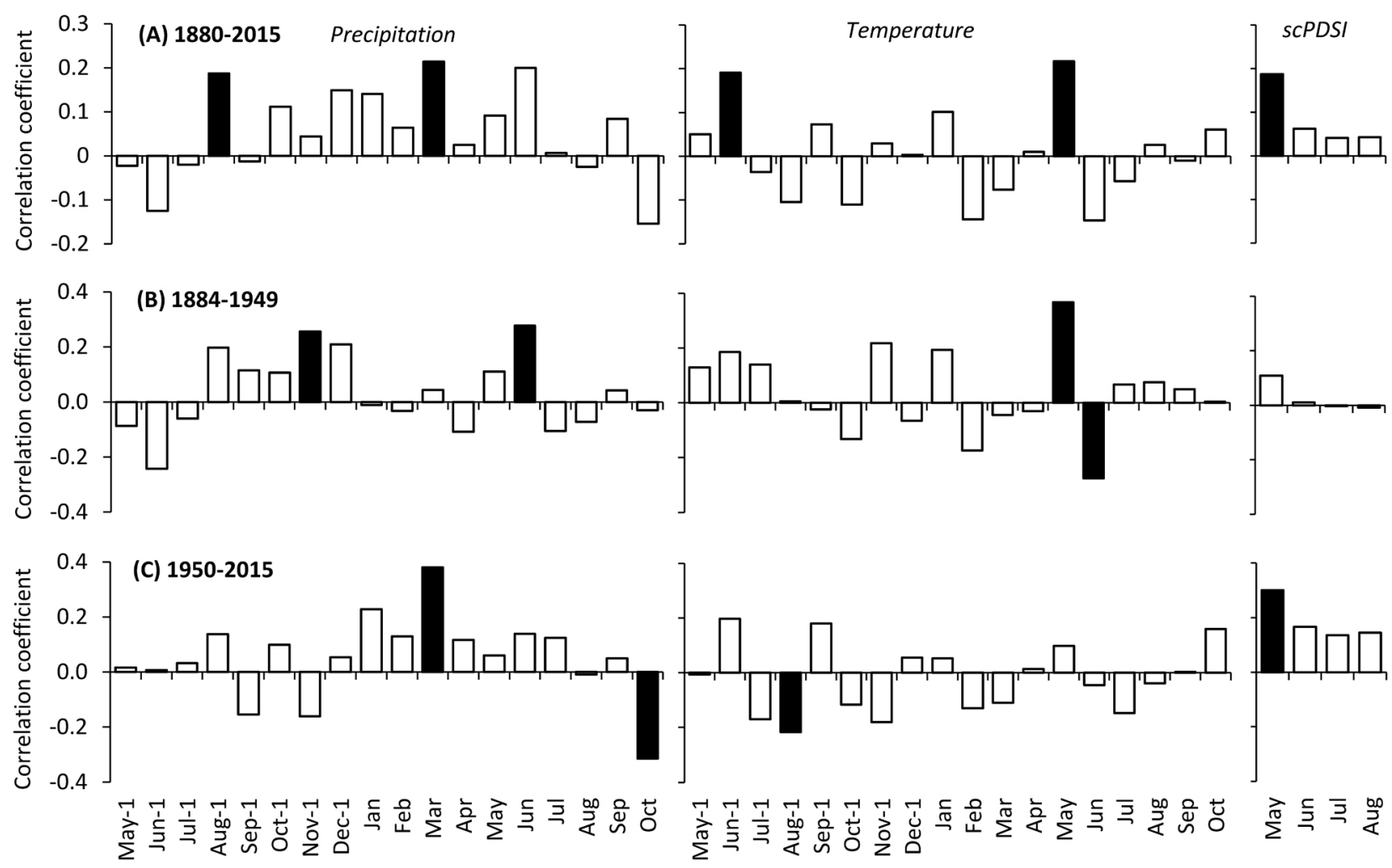

Fig. 3. Correlation between the residual ring-width chronology and the monthly series of precipitation, temperature and the self-calibrating Palmer Drought Severity Indices (scPDSI) for the entire reference period 1880-2015 (A), the 66year interval (1884-1949) prior to the river regulation (B), and 66-year interval over the period (1950-2015) of the river regulation $(C)$. Filled bars denote significant correlation coefficient $(p<0.05)$ 


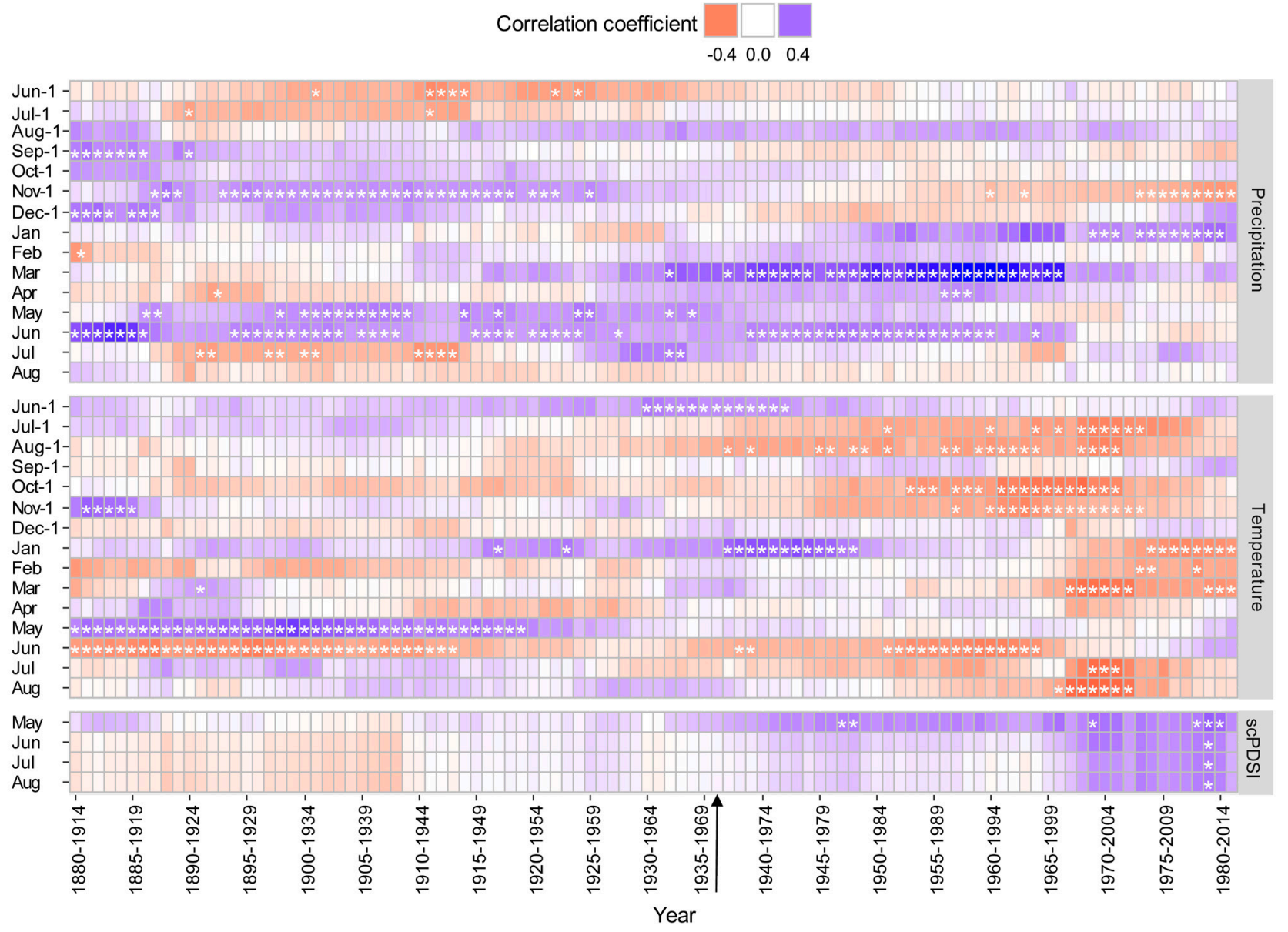

Fig. 4. Thirty-five-year moving correlation analysis between the residual ring-width chronology and the monthly climatic variables from the previous growing season (-1) June to the current growing season August. Statistically significant $(p<0.95)$ values are marked by the asterisk $(*)$. The vertical arrow denotes the interval when the river regulation was implemented

current May (1886-1934), and current June (18801991) precipitation was the most prominent relationship between the oak radial growth and precipitation, although it was not stable over the entire interval. Prior-June precipitation negatively correlated with oak growth in the period from the early 1900s to the mid-1950s. Precipitation in previous autumn-winter (prior-September to prior-December) positively correlated with oak growth during the pre-1960 period, although prior-November effect shifted to being significantly negative after the 1960s. The moving correlation analysis indicated that the correlation between the growth and current February, current April, and current July precipitation reversed during the studied interval. In the recent decades, the only precipitation variables significantly correlated with oak growth were prior-November and current January.

The moving correlation analysis identified that relationships with 13 out of 15 monthly temperature variables were significant during some of the 35-yr intervals (Fig. 4). Only prior-June temperature had a significant positive correlation during the entire interval achieving highest values in the period 1929-1976.
Current May (positive) and current June (negative) temperature had a tendency to become less significant after the 1960s and after the 2000s, respectively. The significant negative relationships with temperature in the previous radial growth season (prior-July, prior-August), intermittent "dormant" season (prior-October, prior-November, January-March), and in the current radial growth season (July-August) developed mainly after the 1950s. Several of the growth-temperature patterns reversed during this period. In particular, prior-November temperature had a positive correlation from 1881 to 1918 , and a negative correlation from 1954 to 2005. The effect of January temperature on oak growth was positive in the 35-yr sequences from 1916-1950 to 1948-1982, and became negative in 1975-2009 and thereafter. The sign of the correlation between current March temperature and growth reversed twice, i.e. from negative (1880-1914) to positive (1891-1925) and later again to negative (1967-2015).

None of the monthly drought variables showed a sustained significant influence on oak growth in the Lisnyky forest (Fig. 4), but the current May scPDSI 
had a strong correlation during three intervals (19461982, 1969-2003, and 1979-2014). ScPDSI over the entire oak radial growing season had a significant correlation during the 1979-2013 interval.
The results of Gershunov's test indicated that changes in the correlation with only prior-November and current March precipitation cannot be considered as spurious fluctuations.
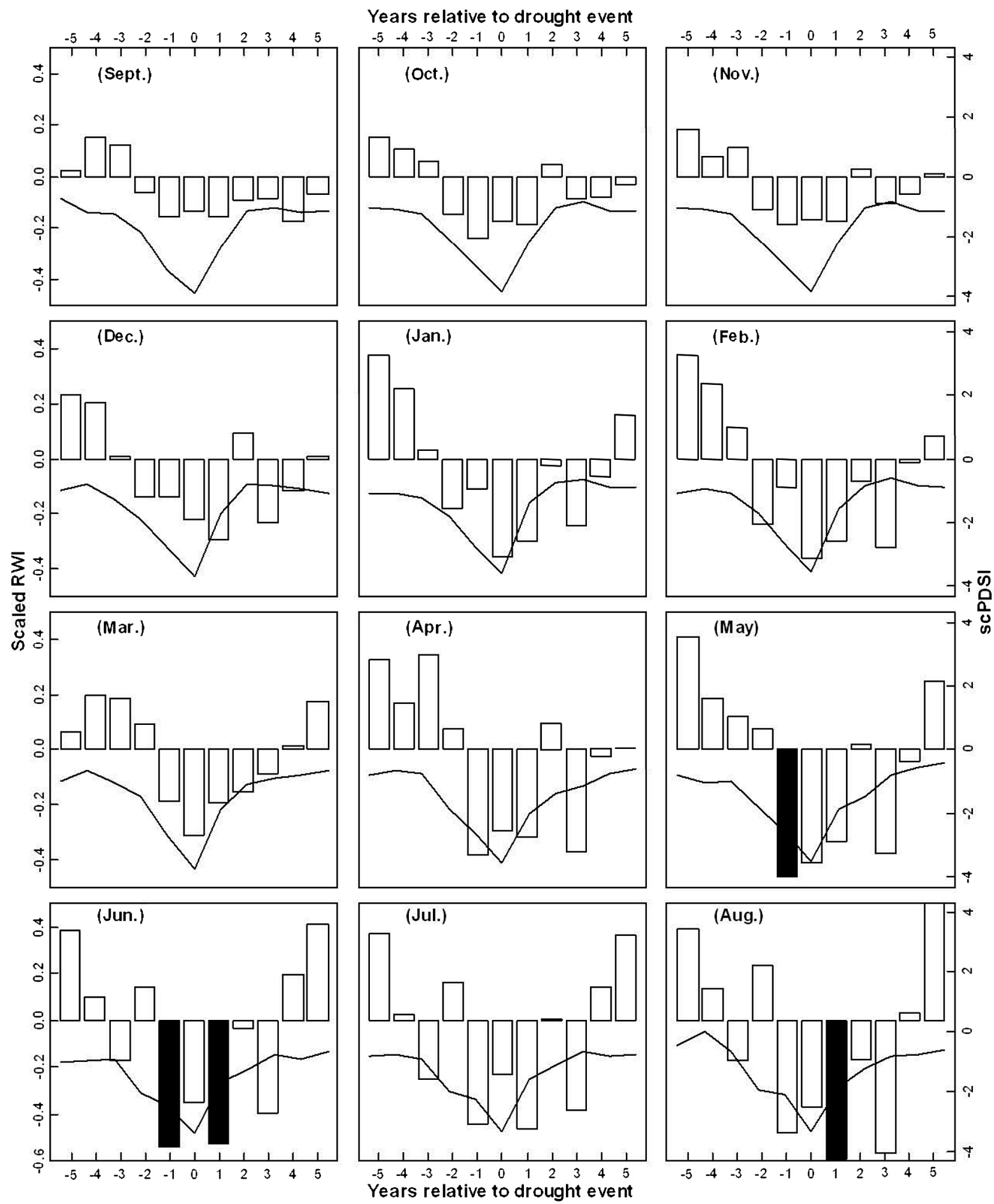

Fig. 5. Histograms of the tree ring response (bars) to droughts expressed by scPDSI (lines). The widths of tree rings are averaged by superposed epoch analysis and scaled. The filled bars denote significance $(\mathrm{p}<0.05)$ of the departures from the chronology mean ring width indices 

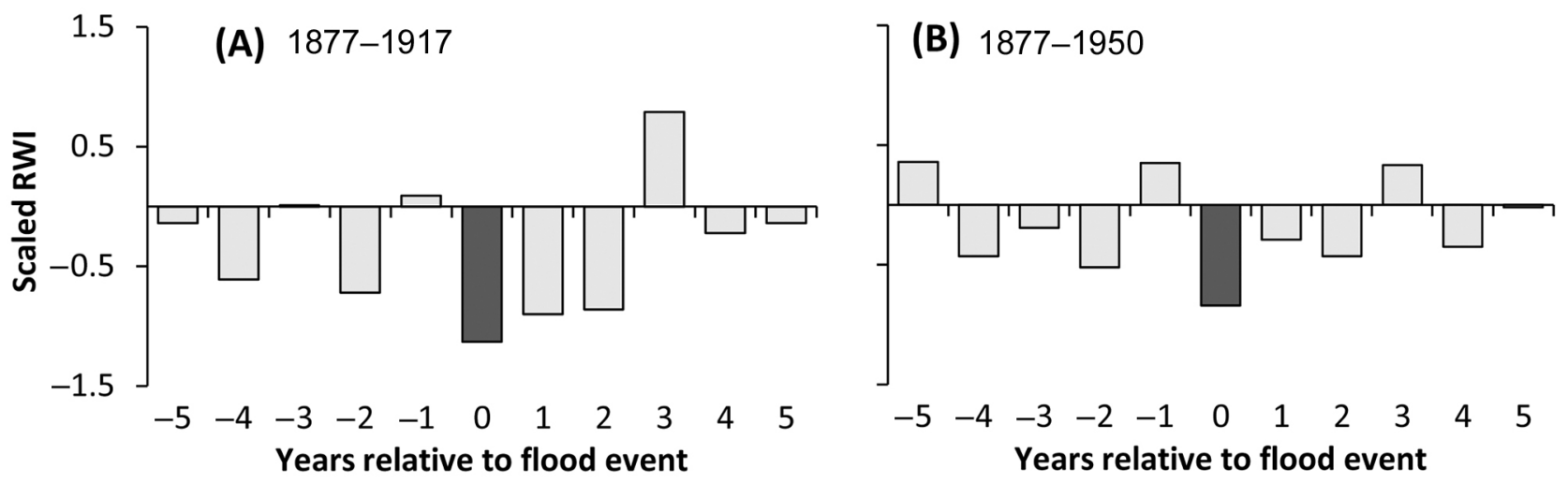

Fig. 6. Histograms of the tree ring response to flood events in the periods 1877-1917 (A) and 1877-1950 (B). The widths of tree rings are averaged by superposed epoch analysis and scaled. The dark-filled bars denote significance $(\mathrm{p}<0.05)$ of the departures from the chronology mean ring width indices

The superposed epoch analysis allowed us to find that a decrease in the scaled tree ring width indices coincided with drought events that occurred only in May, June, and August (Fig. 5). As Figure 5 (black line) shows, the average scPDSI fell below a moderate value $(-2.00$ to -2.99$)$ already one or two years before zero point, i.e. when an extreme drought event $(-4)$ occurred, and then quickly grew. A moderate to severe (-3.00 to -3.99$)$ May-June drought occurred a year $(-1)$ before an extreme event provoked substantial oak radial growth slowdown in the current season, although an extreme drought (year 0) in June and August resulted in growth depression in the next growing season (year 1).

In the period covered by the raw tree ring width chronology, the largest historical floods in Kyiv that occurred in the 1877, 1908, 1917, 1931, 1970, and 1979 coincided with growth decrease in the 1877 , 1908, 1917, when trees aged less than 50 years comprised more than 50 percent of the studied oaks (see Fig. 2). The superposed epoch analysis based on extreme flood events that occurred during the periods 1877-1917 and 1877-1950 showed a significant negative response for $Q$. robur tree ring width (Fig. 6), although the response was stronger in the first period.

\section{Discussion}

\section{Oak growth-to-climate relationships}

The $Q$. robur trees from the Lisnyky floodplain forest demonstrate a well-known age-related downward growth trend with mean ring width value of $2.5 \mathrm{~mm}$ that is inherent in trees at sites with optimal conditions throughout Europe (Friedrichs et al., 2009; Scharnweber et al., 2013; Čufar et al., 2014; Hroš \& Vavrčík, 2014). The ring-width series shows a clear evidence that climate drives oak growth in the Lisnyky forest. The positive correlations with prior-August precipitation and prior-June temperature (Fig. 3 A) are the most prominent in the relationship between oak growth and conditions attributed to the previous growing season over entire the reference period. This pattern is probably linked to the mechanism of non-structural carbohydrates accumulation (Pérezde-Lis et al., 2016a) contributed to cambium activity and vessel enlargement that in $Q$. robur begins before budburst, leaf expansion, and thus carbon assimilation (Sass-Klaassen et al., 2011; Pérez-de-Lis et al., 2016b). In the Lisnyky forest, the June heat significantly diminishing current tree-ring width probably leads to an overall slowdown of the xylogenesis or its cessation (Pérez-de-Lis et al., 2017). Such premature ring growth completion triggers accumulation of soluble sugars and starch providing earlywood formation with readily available energy and material during the next growing season (Barbaroux \& Bréda, 2002; Pérez-de-Lis et al., 2017). The positive growth response to prior-August rainfall indicates that the Lisnyky floodplain is prone to drought in late summer and that water availability in this period may be crucial for carbon assimilation and non-structural carbohydrates storage. This pattern seems to be sustained related to natural regime of the local river that almost dries up in the mid-summer (Vishnevsky, 2007).

The moving correlation analysis revealed other significant relationships with prior growing season rainfall occurring during shorter periods and obviously related to the corresponding climatic trendlines (Fig. $1)$. The correlation with prior-November precipitation, for instance, exceeds the significance threshold two times - first, when a 35-yr average trendline of precipitation falls below the value of $40 \mathrm{~mm}$, and second, when it exceeds the value of $45 \mathrm{~mm}$. Accordingly, the initially positive correlation became negative. Over the period of the general lack of available water in the late growing season, November precipitation contributes to wood formation in the following season probably through promoted root growth (Santini 
et al., 1994). The negative effect of prior-November precipitation may be related to the hypoxia in the roots induced by excess of soil-water in the dormant season (Rozas \& García-González, 2012).

Another prominent feature of growth relationship with precipitation in the pre-growing period is the positive correlation with March precipitation that could only be attributed to soil saturation by water before the onset of xylogenesis. This finding has not been reported for oaks at flooded sites thus far. Given that historically the Lysnyky forest experiences flooding in early spring (Vishnevsky, 2007), the oak growth could be favored by the high amount of precipitation in March, only due to the Siverka River regulation implemented in the 1950s.

Strong positive correlation with current May-June precipitation seems to be a common response pattern of the $Q$. robur over its natural range at sites with various local conditions (Bednarz \& Ptak, 1990; Rozas, 2005; García-Suárez et al., 2009; Friendrichs et al., 2009; Kern et al., 2013; Matisons et al., 2013; Čufar et al., 2014; Cedro \& Nowak, 2015), as well as in floodplain forests (Čater \& Levanič, 2015). This pattern suggests a direct growth response on weather conditions and indicates that the trees may need large amount of water to perform extensive physiological processes (García González \& Ekstein, 2003; Fonti \& García-González, 2008), i.e. evapotranspiration and wood formation, in late-spring - early summer. In contrast, a high amount of precipitation in July can reduce oak growth as figures 1 and 4 show. This feature is likely to be an attribute of flooded or waterlogged sites (Čejková \& Poláková, 2012) and could be related to trends of the regional climate. Thus, the significant negative correlation with July rainfall occurs in the period of minimal temperature, but it increases following interim warming trend after the late 1930s.

The positive response of the Lisnyky oaks radial growth on May temperature is not a widespread pattern and it is common at sites near the northern edge of the species distribution range (Drobyshev et al., 2008; Matisons \& Dauškane, 2009; Matisons et al., 2013, Cedro \& Nowak, 2015) or at waterlogged (Čejková \& Poláková, 2012) and at flooded (Tumajer \& Treml, 2016) sites in Central Europe. This fact imply that impact of regional warming in the Lisnyky forest has been mitigated probably due to the water body cooling effect coupled with canopy shading and evapotranspiration (Hesslerová et al., 2013; Elisson et al., 2017). Micro- and mezoclimate investigations in riparian ecosystems suggest that soil moisture, air humidity, air and soil temperature are different from those in surrounding territory (Brosofske et al., 1997; Danehy \& Kirpes, 2000; Agafonov \& Gurskaya, 2013; Capon et al., 2013; Hadaš, 2003). However, moving correlation analysis identifies the weakening of the growth-to-May temperature association that is probably a result of both rising temperature (see Fig. $1 \mathrm{~b}$ for May) and the Siverka River regulation (see Fig. 3 C, D).

The recent persistent rising trend of a $35-\mathrm{yr}$ average temperature is common for all months with the only difference in its onset. For June-October months, trendlines started to grow around the late 1970s - early 1980s and obviously induced changes in the growth-climate relationship patterns revealed by the moving correlation analysis as a strengthening of the negative correlation with temperature after the 1800s. The shift to a negative growth association with January temperature is probably the most unprecedented change, which is inconsistent with results reported from Northern Poland (Pritzkow et al., 2016), but is in line with recent oak growth-climate relationship patterns in steppe zone in Ukraine (Netsvetov et al., 2017). Most of the factors tightly associated with oak growth in the Lisnyky forest, however, lost their control in the 2000s, which may be related to a climatic hiatus, i.e. the global atmospheric warming slowdown during 2001-2014 caused by a heat sink in the subsurface ocean (England et al., 2014).

The Siverka River hydrology alteration appears to have an influence on oak growth sensitivity to climate variation. The flow was channeled and several reservoirs began depleting its waters both upstream and downstream of the Lisnyky forest in the 1950s. The correlation between oak chronology and spring scPDSI increases following a channel construction and suggests a soil-water deficit during the radial growth season. The moving correlation analysis shows a weakening of correlations with scPDSI in the last 35$\mathrm{yr}$ interval, which may be a consequence of the partial dismantling and the aggradation of the channel. The Superposed Epoch Analysis, however, points to a significant growth reduction in the year of moderate to extreme drought events that happen irregularly. Our observations agree with results from the Sava River floodplain in Serbia, where a low water level and rising temperature were found to depress oak growth during last 30 years (Stojanović et al., 2015a).

Ecophysiological and dendrochronological findings indicate that anatomical, morphological (Tatin-Froux et al., 2014; Copini et al., 2016), and physiological adaptations (Ferner et al., 2012) to root hypoxia allow $Q$. robur to withstand the high ground water level. Flooding mediates the earlywood vessel formation in the submerged stem part in juvenile and mature oaks (Astrade \& Begin, 1997; Land, 2014; Copini et al., 2016) and leads to a reduction of the ring width in the upper stem part in juvenile trees (Copini et al., 2016). Thus, increased tolerance to root hypoxia in mature trees could explain why oaks in the Lisnyky forest lost their sensitivity to high water levels that were in close relations with floods on the Dnipro River, i.e. the 
main stream. The superposed epoch analysis result (Fig. 6) infers the tree growth response on flood in the Lisnyky forest changed due to the aging processes rather than the Siverka River regulation.

\section{Concluding remarks}

We have used a combination of dendrochronological approaches and traditional statistical methods to assess the long-term dynamics of climatic response of Quercus robur in floodplain forest under river regulation. Previous studies utilized rather short-term tree ring chronologies and climatic series not allowing to uncover the effect of natural climate variability prior to hydrology alteration. In the present study, we show that the long-term growth-to-climate response of $Q$. robur under human-induced changes in floodplain is characterized by two distinct patterns with a crossover point corresponding to river flow regulation onset. Under natural conditions, i.e. before river regulation, extreme flooding had a negative effect on oak growth that was also governed by temperature and precipitation in the growth season. Upon river regulation, $Q$. robur trees became unexpectedly sensitive to lack of precipitation in early spring and vulnerable to extreme drought events in the radial growth season. This relationship is rather a coupled effect of the regional climate trend and river regulation, since after partial drainage failure these factors have lost their control on $Q$. robur radial growth.

The shift in the captured climatic signal demonstrates that the local alteration of the hydrologic regime may trigger unprecedented tree growth responses instigated by regional climatic trends. This study emphasizes the relevance of dendroclimatic researches from the flooded sites with altered hydrology for better understanding human impact on trees species growth-climate relationships even in regions with conditions congenial to trees growth.

\section{Acknowledgements}

We are grateful to Andrew Judkins for English language assistance and to three anonymous reviewers for their comments that have helped to improve the manuscript.

\section{References}

Agafonov LI \& Gurskaya MA (2013) The influence of the lower Ob River runoff on radial growth of trees. Contemporary Problem of Ecology 6: 779787.

Astrade L \& Begin Y (1997) Tree-ring response of Populus tremula L. and Quercus robur L. to recent spring floods of the Saone River, France. Ecoscience 4: 232-239.

Barbaroux C \& Bréda N (2002) Contrasting distribution and seasonal dynamics of carbohydrate reserves in stem wood of adult ring-porous sessile oak and diffuse-porous beech trees. Tree Physiology 22: 1201-1210.

Bauer Z, Trnka M, Bauerová J, Možný M, Štěpánek P, Bartošová L \& Žalud Z (2010) Changing climate and the phenological response of great tit and collared flycatcher populations in floodplain forest ecosystems in Central Europe. International Journal of Biometeorology 54: 99-111.

Bednarz Z \& Ptak J (1990) The influence of temperature and precipitation on ring widths of oak (Quercus robur L.) in the Niepolomice forest near Cracow, southern Poland. Tree-Ring Bullettin 50: 1-9.

Brosofske KD, Chen J, Naiman RJ \& Franklin JF (1997) Harvesting effects on microclimatic gradients from small streams to uplands in western Washington. Ecological Applications 7: 11881200.

Bunn AG (2010) Statistical and visual crossdating in $\mathrm{R}$ using the dplR library. Dendrochronologia 28: 251-258.

Capon SJ, Chambers LE, Mac Nally R, Naiman RJ, Davies P, Marshall N, Pittock J, Reid M, Capon T, Douglas M, Catford J, Baldwin DS, Stewardson M, Roberts J, Parsons M \& Williams SE (2013) Riparian ecosystems in the 21st century: hotspots for climate change adaptation? Ecosystems 16: 359-381.

Čater M \& Levanič T (2015) Physiological and growth response of Quercus robur in Slovenia. Dendrobiology 74: 3-12.

Cedro A \& Nowak G (2015) Dendroclimatic investigations on Quercus rubra and Quercus robur in north-western Poland. Dendrobiology 74: 123133.

Čejková A \& Poláková S (2012) Growth responses of sessile oak to climate and hydrological regime in the Zbytka Nature Reserve, Czech Republic. Geochronometria 39: 285-294.

Copini P, den Ouden J, Robert EMR, Tardif JC, Loesberg WA, Goudzwaard L \& Sass-Klaassen U (2016) Flood-ring formation and root development in response to experimental flooding in young Quercus robur trees. Frontiers in Plant Science 7: e775.

Čufar K, Grabner M, Morgós A, Martínez del Castillo E, Merela M \& de Luis M (2014) Common climatic signals affecting oak tree-ring growth in SE Central Europe. Trees 28: 1267-1277.

Danehy RJ \& Kirpes BJ (2000) Relative humidity gradients across riparian areas in eastern Oregon 
and Washington forests. Northwest Science 74 : 224-233.

Didukh YaP \& Aloshkina UM (2012) Biotops of Kyiv. NaUKMA, Agrar Media Group, Kyiv.

Drobyshev I, Niklasson M, Eggertsson O, Linderson H \& Sonesson K (2008) Influence of annual weather on growth of pedunculate oak in southern Sweden. Annals of Forest Science 65: e512.

Elisson E, Morris CE, Locatelli B, Sheil D, Cohen J, Murdiyarso D, Gutierrez V, van Noordwijk M, Creed IF, Pokorny J, Gaveau D, Spracklen DV, Tobella AB, Ilstedt U, Teuling AJ, Gebrehiwot SG, Sands DC, Muys B, Verbist B, Springgay E, Sugandi Y \& Sullivan CA (2017) Trees, forests and water: Cool insights for a hot world. Global Environmental Change. 43: 51-61.

England MH, McGregor S, Spence P, Meehl GA, Timmermann A, Cai W, Gupta AS, McPhaden MJ, Purich A \& Santoso A (2014) Recent intensification of wind-driven circulation in the Pacific and the ongoing warming hiatus. Nature Climate Change 4: 222-227.

Ferner E, Rennenberg H \& Kreuzwieser J (2012) Effect of flooding on C metabolism of flood-tolerant (Quercus robur) and non-tolerant (Fagus sylvatica) tree species. Tree Physiology 32: 135-145.

Fonti P \& García-González I (2008) Earlywood vessel size of oak as potential proxy for spring precipitation in mesic sites. Journal of Biogeography 35: 2249-2257.

Friedrichs DA, Büntgen U, Frank DC, Esper J, Neuwirth B \& Löffler J (2009) Complex climate controls on 20th century oak growth in Central-West Germany. Tree Physiology 29: 39-51.

García González I \& Ekstein D (2003) Climatic signal of earlywood vessels of oak on a maritime site. Tree Physiology 23: 497-504.

García-Suárez AM, Butler CJ \& Baillie MGL (2009) Climate signal in tree-ring chronologies in a temperate climate: a multi-species approach. Dendrochronologia 27: 183-198.

Gershunov A, Schneider N \& Barnett T (2001) Low-frequency modulation of the ENSO-Indian monsoon rainfall relationship: Signal or noise? Journal of Climate 14: 2486-2492.

Glenz C, Schlaepfer R, Iorgulescu I \& Kienast F (2006) Flooding tolerance of Central European tree and shrub species. Forest Ecology and Management 235: 1-13.

Goršić E (2014) Response of pedunculate oak in Balkan floodplain forests to drought. STSM Scientific Report, Ljubljana, Slovenia.

Gren I-M, Groth K-H \& Sylven M (1995) Economic values of Danube Floodplains. Journal of Environmental Management 45: 333-345.

Gričar J, de Luis M, Hafner P \& Levanič T (2013) Anatomical characteristics and hydrologic signals in tree-rings of oaks (Quercus robur L.). Trees 27: 1669-1680.

Hadaš P (2003) Temperature and humidity conditions of the floodplain forest with respect to stand microclimate and mesoclimate. Ekológia (Bratislava) 22: 19-46.

Hafner P, Gričar J, Skudnik M \& Levanič T (2015) Variations in environmental signals in tree-ring indices in trees with different growth potential. Plos One 10: e0143918.

Hesslerová P, Pokorný J, Brom J \& Rejšková-Procházková A (2013) Daily dynamics of radiation surface temperature of different land cover types in a temperate cultural landscape: consequences for the local climate. Ecological Engineering 54: $145-154$.

Holmes RL (1983) Computer-assisted quality control in tree-ring dating and measurement. TreeRing Bulletin 43: 69-78.

Hroš M \& Vavrčík H (2014) Comparison of earlywood vessel variables in the wood of Quercus robur L. and Quercus petraea (Mattuschka) Liebl. growing at the same site. Dendrochronologia 32: 284-289.

Kaminski B, Miler AT, Okonski B, Grajewski S \& Schwartz K (2011) Floodplain forest technical and monitoring solutions for protection of the Uroczysko Warta floodplain forest. Polish Journal of Environmental Studies 5: 1193-1201.

Kern Z, Patkó M, Kázmér M, Fekete J, Kele S \& Pályi Z (2013) Multiple tree-ring proxies (earlywood width, latewood width and 13C) from pedunculate oak (Quercus robur L.), Hungary. Quaternary International 293: 257-267.

Klimo E (1998) History, condition and management of floodplain forest ecosystems in Europe. Environmental Forest Science 54: 173-186.

Kreuzwieser J, Papadopoulou E \& Rennenberg $\mathrm{H}$ (2004) Interaction of flooding with carbon metabolism of forest trees. Plant Biology 6: 299-306.

Kundzewicz ZW (2008) Climate change impacts on the hydrological cycle. Ecohydrology \& Hydrobiology 8: 195-203.

Land A (2014) Holzanatomische veränderungen als reaktion auf extreme umweltereignisse in rezenten und subfossilen eichen und deren verifizierungim experiment. Doktorgrades der Naturwissenschaften (Dr.rer.nat.), Universität Hohenheim, Hohenheim.

Lévy G, Lefévre Y, Becker M, Frochot H, Picard JF, Wagner PA \& Aussenac G (1999) Excess water: effects on growth of oak. Special Issue. Fonctionnement des arbres et écosystèmes forestiers. Avancées récentes et consequences sylvicoles. Revue Forestière Française 51: 151-161.

Matisons R \& Dauškane I (2009) Influence of climate on earlywood vessel formation of Quercus robur at its northern distribution range in central 
regions of Latvia. Acta Universitatis Latviensis 753: 49-58.

Matisons R, Elferts D \& Brumelis G (2013) Pointer years in tree-ring width and earlywood-vessel area time series of Quercus robur - relation with climate factors near its northern distribution limit. Dendrochronologia 31: 129-139.

Middelkoop H, Daamen K, Gellens D, Grabs W, Kwadijk JCJ, Lang H, Parmet BWAH, Schädler B, Schulla J \& Wilke K (2001) Impact of climate change on hydrological regimes and water resources management in the Rhine basin. Climatic Change 49: 105-128.

Morid R, Delavar M, Eagderi S \& Kumar L (2016) Assessment of climate change impacts on river hydrology and habitat suitability of Oxynoemacheilus bergianus. Case study: Kordan River, Iran. Hydrobiologia 771: 83-100.

Netsvetov M, Sergeyev M, Nikulina V, Korniyenko V \& Prokopuk Y (2017) The climate to growth relationship of pedunculate oak in steppe. Dendrochronologia 44: 31-38.

Palmer WC (1965) Meteorological drought. Research Paper 45, U.S. Weather Bureau, Washington, D.C.

Pérez-de-Lis G, García-González I, Rozas V \& Olano JM (2016a) Feedbacks between earlywood anatomy and non-structural carbohydrates affect spring phenology and wood production in ring-porous oaks. Biogeosciences 13: 5499-5510.

Pérez-de-Lis G, Olano JM, Rozas V, Rossi S, VázquezRuiz RA \& García-González I (2017) Environmental conditions and vascular cambium regulate carbon allocation to xylem growth in deciduous oaks. Functional Ecology 31: 592-603.

Pérez-de-Lis G, Rossi S, Vázquez-Ruiz RA, Rozas V \& García-González I (2016b) Do changes in spring phenology affect earlywood vessels? Perspective from the xylogenesis monitoring of two sympatric ring-porous oaks. New Phytologist 209: 521-530.

Poff NL, Allan JD, Bain MB, Karr JR, Prestegaard KL, Richter BD, Sparks RE \& Stromberg JC (1997) The natural flow regime: a paradigm for river conservation and restoration. BioScience 47: 769784.

Politti E, Egger G, Angermann K, Rivaes R, Blamauer B, Klösch M, Tritthart M \& Habersack H (2014) Evaluating climate change impacts on Alpine floodplain vegetation. Hydrobiologia 737: 225243.

Pritzkow C, Wazny T, Heußner KU, Słowiński M, Bieber A, Dorado Liñáne I, Helle G \& Heinrich I (2016) Minimum winter temperature reconstruction from average earlywood vessel area of European oak (Quercus robur) in N-Poland. Palaeogeography, Palaeoclimatology, Palaeoecology 449: 520-530.
R Core Team (2016) R: A Language and Environment for Statistical Computing. R Foundation for Statistical Computing, Vienna.

Rozas V (2005) Dendrochronology of pedunculate oak (Quercus robur L.) in an old-growth pollarded woodland in northern Spain: tree-ring growth responses to climate. Annals of Forest Science 62: 209-218.

Rozas V \& García-Gonzáles I (2012) Non-stationary influence of El Niño-Southern Oscillation and winter temperature on oak latewood growth in NW Iberian Peninsula. International Journal of Biometeorology 56: 787-800.

Santini A, Bottacci A \& Gellini R (1994) Preliminary dendroecological survey on pedunculate oak (Quercus robur L.) stands in Tuscany (Italy). Annales des Sciences forestières 51: 1-10.

Sass-Klaassen U, Sabajo CR \& den Ouden J (2011) Vessel formation in relation to leaf phenology in pedunculate oak and European ash. Dendrochronologia 29: 171-175.

Scharnweber T, Manthey M \& Wilmking M (2013) Differential radial growth patterns between beech (Fagus sylvatica L.) and oak (Quercus robur L.) on periodically waterlogged soils. Tree Physiology 33: 425-437.

Schneider C, Laizé CLR, Acreman MC \& Flörke M (2013) How will climate change modify river flow regimes in Europe? Hydrology and Earth System Sciences 17: 325-339.

Schnitzler A, Brack WH \& Esther A (2005) Biodiversity of floodplain forests in Europe and eastern North America: a comparative study of the Rhine and Mississippi Valleys. Biodiversity and Conservation 14: 97-117.

Siebel HN, Van Wijk M \& Blom CWPM (1998) Can tree seedlings survive increased flood levels of rivers? Acta Botanica Neerlandica 47: 219-230.

Sperry JS, Meinzer FC \& McCulloh KA (2008) Safety and efficiency conflict in hydraulic architecture: scaling form tissues to trees. Plant, Cell \& Environment 31: 632-645.

Stella JC, Riddle J, Piégay H, Gagnage M \& Trémélo M-L (2013) Climate and local geomorphic interactions drive patterns of riparian forest decline along a Mediterranean Basin river. Geomorphology 202: 101-114.

Stojanović DB, Levanić T, Matović B \& Orlović S (2015a) Growth decrease and mortality of oak floodplain forests as a response to change of water regime and climate. European Journal of Forest Research 134: 555-567.

Stojanović D, Levanić T, Matović B \& Bravo-Oviedo A (2015b) Climate change impact on a mixed lowland oak stand in Serbia. Annals of Silvicultural Research 39: 94-99. 
Ström L, Jansson R, Nilsson C, Johansson ME \& Xiong S (2011) Hydrologic effects on riparian vegetation in a boreal river: an experiment testing climate change predictions. Global Change Biology 17: 254-267.

Stuijfzand S, Ek EV, Manen HV, Hommel PWFM, Waal RWD, Pol JVD, Daling J, Pelsma T, Belien E, Olsthoorn A, Sass-Klaassen U, den Ouden J, Kuijper M \& van Rooij S (2008) Onderzoek naar Effecten van Waterberging in een Jong Kleibos: Achtergrondrapport Harderbos, Alterra rapport 1630, RWSW aterdienst rapport 2007.015. http://edepot.wur.nl/41610.

Tatin-Froux F, Capelli N \& Parelle J (2014) Cause-effect relationship among morphological adaptations, growth, and gas exchange response of pedunculate oak seedlings to waterlogging. Annals of Forest Science 71: 363-369.

Tumajer J \& Treml V (2016) Response of floodplain pedunculate oak (Quercus robur L.) tree-ring width and vessel anatomy to climatic trends and extreme hydroclimatic events. Forest Ecology and Management 379: 185-194.

Turner MG, Gergel SE, Dixon MD \& Miller JR (2004) Distribution and abundance of trees in floodplain forests of the Wisconsin River: Environmental influences at different scales. Journal of Vegetation Science 15: 729-738.

Vincke C \& Delvaux B (2005) Porosity and available water of temporarily waterlogged soils in a Quercus robur (L.) declining stand. Plant and Soil 271: 189-203.

Vishnevsky V (2007) Small River Kyiv. Interpress Ltd, Kyiv, Ukraine.

Webb RW, Rosenzweig CE \& Levine ER (2000) Global Soil Texture and Derived Water-Holding Capacities. Data set. Oak Ridge National Laboratory Distributed Active Archive Center, Oak Ridge, Tennessee, U.S.A. http://www.daac.ornl.gov.

Wells N, Goddard S \& Hayes M J (2004) A self-calibrating Palmer Drought Severity Index. Journal of Climate 17: 2335-2351.

Zang C \& Biondi F (2013) Dendroclimatic calibration in R: The bootRes package for response and correlation function analysis. Dendrochronologia 31: 68-74.

Zang C \& Biondi F (2015) treeclim: an R package for the numerical calibration of proxy-climate relationshops. Ecography 38: 431-436. 